\title{
Religion and African Identity: A Reflection on Nigerian Situation
}

\author{
Chizaram Onyekwere Oliver Uche ${ }^{1}$, Paul Ikechukwu Ogugua ${ }^{2}$ \\ ${ }^{1}$ Department of Religion and Human Relations, Faculty of Arts, Nnamdi Azikiwe University, Awka, Nigeria \\ ${ }^{2}$ Department of Philosophy, Faculty of Arts, Nnamdi Azikiwe University, Awka, Nigeria \\ Email: ucheooc@yahoo.com, paiykeo@yahoo.com
}

Received January $10^{\text {th }}$, 2013; revised February $13^{\text {th }}, 2013$; accepted February $22^{\text {nd }}, 2013$

\begin{abstract}
The thrust of this paper is to take a reflection on Nigerian situation of religion and African identity. This systematic and functional position has become necessary in view of rich and deep insight into social functions of religion in building African cultural identity in a globalized world. This exploratory survey makes use of literary, sociological and historical methods and analyzed through culture centred approach. The result shows that religion has rich social functions and if fully tapped will build a cohesive society and progressive African identity based on African cultural values. This will be achieved through collaborative effort of all sundry.
\end{abstract}

Keywords: Religion; Identity; African Identity; Reflection; Nigerian Situation

\section{Introduction}

The task of nation building is of great magnitude, only a few realize. The questionable guest of the contemporary Nigerian for concreteness, relevance and excellence-progress in this area of concern, makes him highly skeptical and to look with askance on thing which to him at face value seem unrelated to his practical needs and struggles. People with this kind of mentality see nation-building as consisting in infrastructural development, technological development, accumulation of sophisticated weapons to guarantee security, development of the educational sector, institution of buoyant economy, possession of all the good things of life etc. on account of this, they question boldly, the relevance of religion irrespective of the great works done by early Christian missionaries. Ogugua opines that religion as a reckonable force creates a mode of collective identity and at times, unity. He adds, religion today seems to be a source of diffusing of identity or else why the politicization of religion? Is it not a way of being heard amidst the trumpeted noise that go with globalization.

It is one's identify that assists in locating one properly that is necessarily and even sufficiently in the world and we argue that religion does it for a people or any group and in sense African traditional religion does it for the traditional African.

Iheoma (1983: p. 13) presenting the position of Justice Lemu writes "one can be morally good without professing any religion. But he stressed that religion is able to improve on whatever level of moral goodness one may possess". Chief Melford Okilo the then Governor of River State stated that "morality is an indispensible ingredient of life". He continued, it is like tea without sugar. Whereas some people drink tea without sugar, the survival of the society does not allow education without morality, religion which for many scholars ground morality is the core of an individual's or a nation's life. We Nigerians in our anthem say:

O God of all creation Grant this our one request. Where no man is oppressed. And so with peace and plenty Nigeria may be blessed.

In this anthem, Nigerians pray God to help them in establishing a kingdom of love, where justice and peace will thrive. Justice is the ligament and oil that holds and lubricates the segments of the society respectively without justice-giving everyone his due, there cannot be peace. The Vatican Council II says that "peace results from that harmony built into human society, its divine founder, and actualized by men as they thirst after ever greater justice". Peace is an initiative of justice. Ezeanya (1979: p. 13) interprets the word plenty in the anthem to mean "plenty of those things that man needs to live a decent livelihood in accordance with human dignity and God's design for man".

Man is made up of body, mind and the soul, likewise the society, adequate development warrants taking proper care of these aspects of man. It concerns itself with more than just taking temporal care of the individuals, rather it involves cultivation of the man so that the state enjoys true goodness. Aristotle according to Ernest Barker (1961: p. 118) holds that "the end of the state is not mere life; it is rather a good quality of life-any polis which is truly so called, and is not merely one in name must devote itself to the end of encouraging goodness. Otherwise, a political association sinks into mere alliance, which only differs in space (i.e. the contiguity of its members) from other forms one alliance where the members live at a distance from one another".

For any project for building the state to make its mark, it must concern itself with tripartite constitution of man, for the state cannot be unless the individuals making up the state are built. The values which are essential for this arduous task of nation building can only be found in the heart of men, building these hearts become a "sine qua non". The scripture says out of the abundance of the heart, the mouth speaks.

The first principle of natural moral law states that good should be done and evil avoided. Man must strive toward the good, this move is towards the source of good too. To this source of goodness, man is dependent. It is here that religion 
comes in. It is from religion that man learns that he has obligation to himself, to others, to the society and even to God, who is the creator of all. Religion is a kind of thread that ties everyone to the supreme reality.

We liken a nation to a building. Religion is the foundation. The infrastructures, economy and education are the pillars and the superstructures are the roof. The foundation is very important likewise the pillars. If religion is bracketed in the life of man, you can have an egoist, an animal with unquenchable desire to satisfy self interest and at best a humanist who may obey laws for pure intellectual satisfaction and if others do not obey same laws, he will likely drop them and join the band wagon.

Religion is a value. It equips man with the principles and means for transforming himself. It gives man hope and makes life meaningful for him. It equally offers him the principles, guidelines and the zeal to transform the society. Religion, no doubt has a vital role to play in the building of a nation. Religion is one, yet there are many kinds; could differentiation of religion, various religions not be man's attempt to put order in the world especially with regard to natural religion like African traditional religion, inventions of the mind? One may ask, can religion tell us absolute truth about life?

\section{Religion, What Is It?}

Since the study of religion interests people with different orientations and interests, it is perceived, conceived and defined differently. Some tend to hold that it is whatever anyone believes vehemently in. It can be science, sports, money etc. But is religion just simply belief? Does it begin and end with belief? It does not. We may say it is the search for meaning and purpose in life. Little wonder, Olusegun Oladipo (1995: p. 83) described it as a belief and an attitude. It is a belief that God created everything and everything is dependent on him. Uche (2009a) classifies the belief in God as the structure of African traditional religion. It is an attitude, because it is devotional and expresses our dependence on him as the ultimate reality in terms of whom human existence can be explained. The question is, is religion only a belief and an attitude. It does seem it is equally an activity, and as an activity it is distinguishable from other kinds of human activities like playing, working, dancing etc.

Religion expresses a kind of relationship between God and man. As a belief, it is otherworldly, it stretches to the realm of the spiritual but as an attitude it is "this-worldly". Alston pointed out some characteristics of religion such as belief in supernatural being, distinction between scared and profane, ritual acts focused on sacred objects, a moral view more or less organization of life based on the world view, code, characteristics religious feelings prayer, world-view a social group bound together by the above. He did not point out one, the first which has to do with the supernatural.

Etymologically, religion is derived from three Latin words "religare"- to bind, "relegate"- to unite, or to link and "religi" -relationship. It is an experience that unites man with God. According to Bouguet, A.C. (1941: p. 16), it is "a fixed relationship between the human self and some non-human entity, the scared, the supernatural, the self-existent, the absolute or simply, God”. Schleiermacher (1963: p. 12) qualified the kind of dependence on God thus, "religion is a feeling of absolute dependence on God". But is it feeling? Religion is an activity.
Widery holds that "religion is a form of experience with specific attitudes, with distinctive emotional states, leading to particular kinds of conduct”. This kind of conducts will relate to God and man. Egudu sees religious experience as involving attitudes and emotional states. It does seem that these will then aid in shaping the human conduct talked about. Uche (2011) sees religion as contributing to sustainable development in Nigeria.

Martino James sees religion as a belief in an ever living God, that is in a Divine mind and will ruling the universe and holding moral relations with mankind. It becomes pertinent for one to over look the social or human aspect of religion in the bid to define it.

Ogugua wrote elsewhere "To understand religion properly, we have to bear many things in mind. The realities that are involved in religion are the greatest such as God human person (attribute not excluded) and the world. On account of the magnanimity of the realities involved in religion one agreed upon definition is very difficult". Elsewhere, he wrote religion is a complex phenomenon having dialectical relationship of the mind to reality... in this process; it opens a new dimension in human existence.

Dupre says it is never an aprior definable reality. Arinze (1970: p. 8) pointed out some elements involved in religion dogma, worship and moral. For Wilson, these elements are belief, authority, morality and rituals/worship.

It is pertinent here to point out that religion and morality are not same. Morality does not need religion, but religion needs morality in order to be genuine and acceptable. Omeregbe (1993: p. 2) holds that "in relation to morality, religion is simply a perspective - one of several perspectives - from which morality can be viewed". Religion is not an aspect of man's existence. It is rather the core of man's being; for in it all significant questions of ultimate dimensions are addressed and ultimate answers offered.

\section{The Nigerian Situation}

We have expressed that religion has "this" and "other"world aspect. The question is how has this nation been able to marry these as we have implicitly posited that religion need to be moralized if it must be seen and accepted as being genuine, significant and meaningful.

Nigerians like other Africans are religiously religious. Nigerians are keenly religious. Has the resurgence of religious fervor among them paid off in awakening a life of morality and rectitude? The fact remains that every Nigerian subscribes to one religion or the other. There are a lot of religious sects in Nigeria. The multiplicity of religious groups in Nigeria boggles the mind and smacks the imagination of every right thinking Nigerian in every religious sect formed, before long will have adherents most especially if the founders or the leaders have a charming, kind of charismatic character with the ability to perform one or two miracles irrespective of the sources of their power.

The increase in the number of religious sects most especially in the Christian fold has not been matched with moral uprightness among the people. The level of moral degeneracy in our society is bewildering. Akinpelu (1983: p. 45) holds... "the summary of it all is that in almost every direction you turn, even in the church and in the Mosque, the moral standards of the average Nigerian are very low indeed”. Adegbite (1971) 
had pointed this out earlier, he said our society is corrupt to the core and that is an open secret even to the outside world who knew as much better than we know ourselves.

This is the present state of our public morality. The fact is that our moral atmosphere is stinking. There is immorality and corruption in high and low places, even in the churches. Uche (2007) avers the preservation of African cultural values in stemming the immoral disposition of man. Our conditions are unsettling. Iheoma (1995: p. 23) x-rayed the Leprous situation of the nation thus. The roots of Nigeria's imbroglio are to be founded in the fact that the nation is in the fund of throes of the moral crises. The ominous features of the moral climate of our country are ubiquitous and conspicuous even to a casual observer, rampant fraud, endemic corruption in high and low places, bribery and stealing and robbery with violence, scandalous nepotism, political patronage and obuse of power, excessive materialism which is fast becoming the dominant value of the Nigerian society. Materialism has not only imprisoned our imagination, it is a god that many Nigerians worship at it's altar and have vowed to increase their devotion to it. Adding his voice to this, Ezeani (1986: pp. 17-18) wrote Nigeria is "a country skinned of love CARTIAS CHRISTIANA, but clothed with hatred and rancor... autoism personalism, familism, brotherism, sisterism, girl-friendism... embezelentism, mismanagementism, money-transportationism..."

In this country, the opinion of the poor counts less if it does count at all. Elections to different positions of leadership are rigged and public "elected" officers handpicked. It rhymed with the observation of Ahao, in Times International in all societies, the opinion of the poor counts very little while his vote is not so essential for it lacks economic base.

Our problems are multi quam plural, in every field of life; even a child notices that things have fallen apart. We are dancing to the tune of destruction Nwokolo (1984: p. 25) supports our assertion thus "corruption in Nigeria is today the greatest impediments to national development... New techniques for its advancement are being perfected daily and many believe that it has now reached 'Guinness' book of records dimensions”. We have an odium of dishonesty, corruption and immorality that Nigerians do not walk along the streets of nations without facing one sort of humiliation or the other. To be a Nigerian, is to be corrupt, dishonest, immoral and guilty until you prove you are not, instead of the other way round.

Experience has shown that sermons alone from our leaders cannot do the job of recasting the morally weak Nigeria, Chinua Achebe pointed out clearly that our problem is squarely failure of leadership. We have a breakdown of the nervous system; there is degeneracy in the spirit, soul and body of this giant of Africa. Nothing can nourish the spirit save religion and morality, the body can be nourished by in our instance economy and politics of food, in Okere (1983: p. 54) wrote "if the spirit is starved of religion it atrophies, And the society where spiritual side of life is under developed eventually degenerates and disintegrates".

Is immorality in our blood? Is corruption a cultural trait of Nigerians? It is not, history has not recorded any great civilization anywhere in the world that has not risen under the canopy of a great religion. Iheoma (1995: p. 21) wrote "the renewal or continuation of human existence necessarily includes the renewal of social life through the transmission of beliefs, values, ideas and social standards from one generation to another". "It becomes the concern of this paper to look at the role religion is going to play to ensure that its central objectives are realized in Nigeria. These objectives are ideal qualities of human existence; self-realization and sense of community or brotherhood. In the words of Radhakrsman a quest of emancipation from the immediate compulsions of vain and petty mood”. How will religion aid in bringing about nation building?

\section{Religion Is a “Sine Qua Non”}

Religion is indispensable in our national goals, integration and reconstruction because of its very nature. Religion is a "what" and a "how" of life. It tells us what to believe, what should be done and how to go about what to believe, what should be done and how to go about it. It sheds light on the nature of the supreme reality, the nature of man, the origin of man, the dignity and final end of man. Uche (2004) takes a functional role of religion as a matrix of culture.

Religion confers identity on a people or group. The identity which African traditional religion gives the African is not and cannot be determined and stamped that irrespective of conditions and factors it must be so, rather it is dependent on how Africans did exercise their freedom, such gives a character and by that they are identified. It is so for there is high level of indeterminacy in life and there is no known or established law that has said that there must be only one effect attached to a course, the truth is that there could be multiple effects which a cause has the propensity to attract. Dukor (2010: p. 136) rightly pointed out thus: "The identity question, apart from the associated problems of freewill and choices, is a big problem itself, because as human nature, its predictions can or cannot be about its substance and hope. Prediction is much more possible in the inorganic but less in the organic and in particular, human thought and action".

Religion gives identity to man and no doubt different religions give identities, but these identities could be harmonized. Little wonder, Dukor asserted that identities can be reduced to one. We do accept it because at the level of possibility, anything can happen. But we know and we believe you do know too that we exercise our freedom, make choices and these vary and change which is a reality in life and a constant presenting variation; and we recognize variety as the spice of life.

We must not overlook the fact that it was our forebears response to existence that birthed African traditional religion, which was their response to necessity, which in turn points at our identity, triggered in the pulse, pull and pressures of moral, psychological and/or existential crises. Dukor (2010: pp. 137138) cites Faupal thus: nature does not but "choose" to change overtime, it does so by chance variation about parental norms so that those variations themselves become new norms from which again, chance variation occurs in the next generation. And whether any of these variations survive or not depends largely on their compatibility to the environment in which they find themselves again by chance...”

\section{Religion Is Necessary in Life: It Is the Core of Life}

For the Africans life is religion and religion is life. It is not enough for one to hold that religion is an aspect of life; rather it is at the core of life. In short, it is the core of unthinkable to divorce religion from life in African understanding. The African acquires religion by being part of his society; little wonder 
Uche (2009b) articulates the socio-religious significance of taboos as social sanctions promoting cohesion, solidarity and unity in Africa.

Mbiti Penned (1970) religion permeates all departments of life so fully that it is not easy and possible always to isolate it... Religion is the strongest element in traditional background, and exerts probably the greatest influence upon the thinking of the people concerned. Life is not possible for the African without religion. Mbiti (1982: p. 195) cements it thus, "Religion is a universal part of human life. It must, therefore, have a great and important value, otherwise by now most people in the world would have abandoned it completely".

That religion runs through the veins of the African is a truism. Bishop Shanaham did observe this. John Jordan (1971: p. 115) penned the observation of Bishop Shanaham thus: that the average native was admirably suited by environment and training, for an explanation of life in terms of the spirit rather than of the flesh. An unreligious life worth's nothing to the African, in short, it is not possible. Pope Paul II (1968: p. 8) echoed the same thing about Africans.

"The constant and general foundation of African tradition is the spiritual view of life". Christianity is a gospel of salvationsalvation of man, the entire man hence permeates every aspect of human life. It is a "what" of salvation a "how" of salvation, hence it is a practice religion. It recognizes the duo nature of man-that man is made up of body and soul and tries to touch on these aspects. It is a religion of the whole person.

The Islamic religion does permeate through the entirety of man. Ajibola (1975: p. 147) writes in the entire scheme of Islam, the body is indissoluble linked with the soul. The soul is not a product of the body but is so linked with the body that whatever happens to one affects the other directly or indirectly.

\section{God Occupies a Unique Place in Religion}

The Supreme Being occupies a unique place in the religious life of the people of Africa. Belief in Him is common place everywhere in Africa. It is taken for granted. There is not a single African who does not believe in God. Mbiti (1975: p. 40) buttresses this thus: All Africa people believe in God. they take this belief for granted. It is at the centre of African Religion and dominated all its other belief. He is seen as the power that governs and sustains creation and every thing in existence. Pope Paul II (1968: p. 19) pointed out the place Africans give to God when he wrote: "In this spiritual concept, the most important element generally found is the idea of God, as the first ultimate cause of all things". Africans do believe in other divinities and deities but as they are messengers of God to take care of some departments of life.

Christianity accords a unique place to God head, but talks of three persons in one God. It talks of God the father, God the son and God the Holy Spirit. There is unity in three persons in one God. The scriptures talked about the coming of Jesus centuries before his birth. Mathew 1:23 talked of the virgin that would be with a child, a son of God who will be called Emmanuel-God with us. While Philip in John 48 asked Jesus to show them the father, Christ replied as in John 14:10 Do you not believe that I am in the father, and the father in me?

Again, Christ told the apostles that if he does not go home, the parachute will not come. He established the thread of this unity. Christianity gives prominent position to the Trinity. Islam equally preaches and lays emphasis on the unity of God.
Ajibola (1975: p. 143) writes, Muhammad "emphasized the unity of God whose creation was a visible sign of his presence but who in His essence was invisible”. The Holy Quaran (exll: 2-5) hold.

Say, He is Allah the one! Allah the independent and Besought of all. He begets not nor is He begotten. And there is none like unto Him Muslims believe in Salat (prayer) Saum (fasting), Zakat (poorate, Haji (pilgrimage to Mecca) etc.

Christians believe in almsgiving, praying and fasting too. Traditional religionists do believe in these also. Ezeanya (1979: p. 15) writes "for his overall well being, progress, security, protection from his enemies, recovery from sickness, man must have constant recourse to them by prayers and sacrifices of different kinds".

\section{Human Dignity}

For the African, man is at the centre of the universe. God made him (man) a focal point of the universe, that God and the deities, and divinities are at the service of man. Parrinder (1970: p. 85) presented the views of some scholars on African traditional religion thus "At the apex was God the Supreme Being, on the two sides were the great spiritual powers manifested in gods and ancestors, and at the base were the lower powers of magic. In the middle was man under the influence of many different kinds of power".

Human life is considered sacred; hence everything is done to preserve it. Little wonder, the Igbos denial of formal burial to anyone guilty of suicide. Basden (1966: p. 58), Chinua Achebe in Things Fall Apart; Ezeanya (1976: p. 6) buttresses this point as regards his respect to life. "Even a cursory glance at the traditional religious practices of the African shows it is anthropocentric in the sense that all the religious practices invariably point to one objective, namely LIFE and its preservation”. When sacrifices and prayers are offered to God; and evil spirits as the case may be, the aim is to preserve the life of man.

Ezeanya (1979: p. 16) writes, "The sacredness of life according to many African traditions cannot be applied universally to include every human being in the same degree”. It does look that not every human being has dignity as some are even killed to bury others. Where human beings were killed, it was done to fulfill religious obligations. Ezeanya (1976: p. 9) has this to say; the killing was done "either to satisfy the demand of a divinity for a human victim so that a community might not perish or because it was necessary to give a departed chief some retinues to accompany him to the land of his fathers... where twins were killed, this was done because it was felt that it was unnatural for a human being to imitate lower animals. Similarly, children who were born with feet foremost perished because such "abnormal" births were regarded as a crime against the "mother earth". Apart from these noticed in the distant past the human person was respected.

Christianity is known for the kind of position it gave to man. The Holy writ says that God created man in his image and likeness. The book of Genesis 1: 26-27 says "Then God said, 'Let us make a man-some one like ourselves, to be the master of all life upon the earth and in the skies and in the seas"”.

So God made man like his Maker. Like God did God make man; man and maid did he make them. Every other work of creation stand on a different footing in respect of its relationship to God. Only man has a different kind of relationship to God-a direct immediacy to Him. His dignity and respect arise 
from being made in the image of God. Von Rad (1965: p. 144) emphasizes on this great position of man thus: "On the topmost step of this pyramid stands man, and there is nothing between him and God; indeed, the world, which was in fact made for him, his in him alone its most absolute immediacy to God. Also, unlike the rest of creation, he was not created by the word; but in creating him God was actuated by a unique, solemn resolve in the depths of his heart". God did an extra job to create man. He thought deeply and used his hand and the clay and breathed the vital spat. In short, man's creation took the heavenly dimension.

God did not stop there. He gave man authority and responsibility. The Holy Bible says in Gen. 1:28 "And God blessed them and told them, "multiply and fill the earth and subdue it; you are masters of the fish and birds and all the animals". Erhueh (1989: p. 74) buttresses "dominion over the vast universe is another theological foundation of human dignity. Because man is lord of the whole world, it goes without saying that man has higher dignity than all other creatures in it”. Man is a being open to God, in dialogue with God.

Man in Adam lost his dignity when Adam fell from the state of grace. Man's dignity was restored when Christ - the word of God took flesh. Flannary Austin (1975: p. 923) writes "for, by his incarnation, he, the son of God, has in a certain way united himself with each man". Christ through his resurrection raised man to the dignity of sons of God.

Islam too does accord respect to the human person. Ajibola (1975: p. 149) writes "Islam is not earth-rooted but it never ignores the fact that man's physical frame was fashioned out of clay and he cannot ascend to heaven without first planting his feet firmly on earth". Muhammad (1975: p. 149) writes "he realized that the dignity of human life cannot be preserved without economic security, and social justice is to a very large extent, based on economic justice”.

\section{Human Destiny}

Africans believe that there is life after death. It is generally agreed upon that the life beyond is determined by the life here below. Awolalu, (1972: p. 116) writes "one central theme runs through the African concept of man's destiny: namely, that at death, while the carcass is buried in the earth, the essential person passes on into another life, it is held responsible for deeds or misdeeds, and it is rewarded or punished accordingly by the author of life. Thus in Africa it is strongly believed that death does not bring an end to human life. There is in man an element which is immortal; and this sense of immortality gives comfort in privation and misfortune and as a revenge to death".

Ajibola writes, "the unity of God, prophethood of Muhammad (peace be upon him) and the concept of life after death are the basic articles of its faith. So Islam believes in life after death". Christianity is a way of life. It equally preached that there is life after death. In short, it is concerned more with life beyond than this present life. Ajibola (1975: p. 144) writes "Christianity cannot provide any solution to the burning problems of the day as Christianity does not have any plan for man to live on this earth... the religious man is expected to despise the good things of this world and the next world will compensate him for what he lacked in this mundane existence. The poor are asked to suffer in patience for a short while for their existence on earth after all is very transient”. He has pointed out that Christianity talks about and believes in life beyond the grave. The truth is that Christianity equally concerns itself with solving problems which afflict man in the "hic et nunc". Christianity is too clear that after death comes judgment and that the dead is either rewarded in heaven or is punished in hell. Christianity is surer than every other religion where man goes after death, for Christ is the founder. Christ said in John 14:6 "I am the way, the truth and the life. No one comes to the father except through me".

Elsewhere he said in my father's house are many mansions, if it were not so I would have told you. He promised his apostles that he was going to prepare a place for them, this implies, life beyond the grave. The existence of life after death influences man's present life for "everyone” makes strenuous efforts to live a life that is capable of leading him to life eternal. This is why men aspire to live a life of very high standard of morality. Nobody wants to be separated from his ancestors, good men of the past and God himself, the source of life and goodness.

Though moral judgment need not be made on identity, the appreciation of identity could engineer judgments of a sort, that could aid in enhancing human dignity and sustaining it., belief system underscores identity, and beliefs are powerful and need not be tied to traditions though some beliefs do qualify as traditional. Even though there are ripples in the discourse on African identity, it is agreed upon that African traditional religion confers a sort of identity on Africans.

African Traditional Religion (A.T.R.) can make frantic efforts to rediscover, redefine and integrate African identities and not allow the other currents to impose unduly identity that is contrary and injurious to African identity so as to restore and maintain the prestige of the African. It will be the duty of us Africans, not to be identity-less, by maintaining that the cloak of globalization should not becloud us, and make us an appendix or map us out of the sphere of existents. If we remain firm then, African traditional religion has contributed to the global pull and terrain of building a more balanced contemporary man.

We must not allow the euphoria of what is European make us absorb so much from the west or occident as to lose our identity. We must refuse to be engulfed by the other and dance our own dance in the universal playground. We sell our birthright, if we lose our identity, we must preserve it. Dukor (2010: p. 157) asserts, "we take identity as something that is both physical and transcendental. In actual fact, ancestralism is something that is unique to the Africans which is metaphysical but in the ethical realm”.

\section{Implications of These Values of Religion}

Mbiti (1982: p. 44) said God has been qualified as "creator, creator of all things, moulder, begetter, bearer, maker, potter, fashioner, architect, carpenter, originator, constructor, and so on". The Africans believe that he is constantly at work. Mbiti adds "the people speak of God as the keeper, up holder, preserver, prosper, guardian, caretaker, pastor and saviour”. It is expected that God must have a pride of place in the life of the individual and the nation if the nation must survive and prosper.

Traditional values propagated by African traditional religion has been thrown to the wind, and our leaders ignorantly think they can build Nigeria without recourse to God. Christianity equally knows and preaches that God must be given a place of honour in our lives and the life of the nation. The psalmist says "unless the Lord builds the house, those who build it labour in vain”. Fathers of the Vatican Council II hold as Flannery said 
"we do honour to your authority and your sovereignty, we respect your office, we recognize your just laws, we esteem those who make them and those who apply them. But we have a sacrosanct word to speak to you and it is this: only God is great. God alone is the beginning and the end. God alone is the source of your authority and the foundation of your laws”.

In Islam God is given a place of honour (A1 Quaran 11: 163) says your God is one God; there is none save him, the all-loving, the all-merciful. Again in (CX 11: 1-4) it says.

He is God, the one; God, the eternally, besought of all, he begetteth not, nor was he begotten; and there is none comparable unto him. Religions know that the individual and the nation cannot survive without God, hence appeals that the state be anchored on God. Morality flows naturally from religious beliefs. The belief in life beyond the grave which is determined by the quality of life lived here necessitates man's struggle to live a morally sound life here below. As the life of a person affects that society, the individual strives to ensure that his way of life does not precipitate calamity on himself and society. It is a logical consequence of the Africans belief in the close relationship between man and the powers that steer the course of nature and human destiny.

Little wonder, a lot of sacrifices are made by the people in order to keep the balance in nature, the awareness of the fact that the powers will always punish evil, that brought about the prevalence of law and order in the traditional society. Mbiti (1975: p. 181) stresses “African religious beliefs, values and practices are directed towards strengthening the moral life of each society. Morals are the food and drink which keep society also breaks down and the end is tragic..." with the belief in religion, it has made lasting contribution for religion emphasize the relevance of morals in religious practices and insists that moral be extended into every aspect of life for the good of the individual and society. Religion is and remains the core of the human life.

Christianity, for instance, lays bar man's capacity for good and evil, his passions, the principles of social justice, the nature of mortal life, its transitory nature and how man's values can be reordered. These values enunciated by religion are necessary for true development of man and the society. The development we talk of here is complete development in which man is alive to his responsibilities. He cannot be so, unless he is alive in his dimensions as an incarnate spirit. It is the development of the human agents that is at the root and foundation of other phases of development. It is this being (man) who though influenced by society that eventually through his thoughts shape society.

Religion should aid in the reconstruction of society by helping to make man qualitatively better, this can be done by striving to bring about a new type of man who will have humility as his strength for God is very simple and humble, a man whose integrity will be his greatness.

Since the problem of the contemporary man is that of the spirit, it is metaphysical, only religion can reach the depths of man's being and heal it. Ajibola (1975: p. 146) holds "religion is something that human nature demands. It is said that there are basic human needs; food, clothing and shelter. These are physical needs. Beyond these are spiritual needs as well which science and philosophy fail to satisfy. As the human stomach requires a home to live in, so the human mind also requires certain things and one of such things is the consolation from the questions which beset the human mind...

Religion fulfils the spiritual requirements of man by provid- ing for suitable answers to fundamental human problems. "He continued "the body must be looked after to become fit, strong and pure in order to help the harmony of the spirit”. Religion should aim at liberating man from bondage in every aspect of his life here on earth. It should aid in liberating him from egotism, tribalism, ethnocentricism, materialism, nepotism, embezzlementism, god-fatherism etc. This will aid him to develop a responsible conscience. Okolo (1979: p. 21) writes "the problem of modern man is that of the ordering of values, the curbing of appetites, the appreciation of higher and more permanent good in the midst of the fleeting goods of the senses, and so on”. Nigeria needs men of substance, men of conscience, who have acquired the grace to keep their passions under control, these are men of moral worth, probity and integrity. These are the people who can make an impact in life and not necessarily men of technology.

For any true development to take place in Nigeria, man must be seen and taken for what he is if he is not built, nothing works. Religion directs its concern to the whole person and not just an aspect. This is why it is the core of man's life, not even an aspect.

It is then bizarre to make a sharp distinction between the temporal and the spiritual; for achieving perfection in one without the other is destructive. It is the same man that is the citizen of here below and heaven. Religion should stress the need for the integral development of man and society. Ajibola (1975: p. 147) called Muhammad a practical idealist. He writes "Mohammed (peace and blessings of God be on him) transformed all honest work into worship. He said that the man who is seeking livelihood for his family is also worshipping God”. The wage earner is a friend of God. The gospel did show that Christ was concerned with both the spiritual and physical needs of man. John 10:10 says Christ came that man may have life and have it in abundance.

Religion aids man to reorder his fundamental options, perspective and values. It shows us the real things, which are not in the transient things. Religion arouses man to a new awareness of self, to his ontological vocation to be a subject, an architect of his person and the transformer of his environment. Religion is active, and transformative. Paulo Freire (1973: p. 76) recognized this in his statement "human existence cannot be silent, nor can it be nourished by false words, but only by true words with which men transform the world... men are not built in silence but in word, in work in action-reflection”. By implication, religion in the course of urging men to cater for themselves, work and transform their society is social, for a bond is created between God, man and nature is created hence it is progress and development oriented.

It is on account of this that religion is said to engender the spirit of patriotism in the people. Okoye (1977: p. 14) writes; "it has its moral foundation in piety and social basis in the community". Religion should try to arrest or address the factors which made it difficult if not impossible for citizens to show love and loyalty to the nation.

In the past, in the traditional circles, men exhibited high degree of patriotism, that even some freely gave up their lives for their communities to live and others made great sacrifices for their people. This devotion was linked up with religion. Ezeanya (1979: p. 17) observed "this patriotism, limited though it may be in scope, has nevertheless provided a sound basis for patriotism in the present day Nigeria". The truth is that everybody has a part to play in the reconstruction of society for eve- 
rybody is important and has mission not only in Nigeria but on earth, if the music produced by nature must be harmonic.

\section{Concluding Remarks}

Nigeria, for instance, is a nation made up of nations; she aspires for greatness and had already dubbed the cap the giant of Africa. The aspiration is noble but she must be ever ready to pay the price which is enormous. If we want a just society where everyone is given his due, want to enjoy peace, internal cohesion, progress and prosperity she must make room and give the pride of place to the author of peace, who is the source of all that is good. Nigeria made the first mistake at independence when she adopted the Anthem that hailed Nigeria before thinking of God. Religion is an indispensable recipe, ingredient for building a happy and stable nation. Why? It is because religion gives man an identity.

Etienne Gilson (1960: p. 10) rightly said "just now, states are beginning to realize that they are not equipped to provide themselves with the kind of citizens they need. They do not need citizens merely, but law abiding citizens, ..." Building a nation without religion is like building a massive edifice upon sand. Definitely the slightest gust of the wind will crumble the building. Every religion believes that the world is peopled by spirits and God, hence man is expected to live in such a way as to make his life acceptable to these powers that people the world.

Fulton Sheen (1954: p. 244) said, "it is man who has to be remade first, then society will be remade by the restored new man... The constant refusal of man to allow a supra historic Divine Power to break into his closed mind is the pride which prepares catastrophe". The religions of the world need meet each other in a fraternal spirit of dialogue in order to reconstruct their visions, focus and the nation. Anchoring on the rich religious, moral and spiritual foundations of our forebears will do much in this job of great concern.

\section{REFERENCES}

Adegbite, J. A. (1971). Education for public morality. In J. A. Akingelu, O. A. Nduka et al. (Eds.), New perspectives in moral education. Ibadan: Evans Brother (Nigeria Publishers) Ltd.

Ajibola, A. D. (1975). The myth of the cross. Pakistan: Islamic Publications Ltd.

Akinpelu, J. A. (1983). Values in Nigeria society. New perspective in moral education led by O. A. Nduka et al.

Arinze, F. (1970). Sacrifice in Ibo Religion. Ibadan: Ibadan University Press.

Awolalu, J. O. (1972). The African traditional view of man. Ibadan Journal of Religious Studies, 6, 2.

Barker, E. (1961). The politics of Aristotle Oxford. Oxford: Oxford University Press.

Basden, G. T. (1966). Among the Ibos of Nigeria. London: Frank Coss \& Co. Ltd.

Bought, A. C. (1941). Comparative religion. Middlesex: Penguin Books.

Dukoh, M. (2010). African philosophy in the global village. Berlin: Lambert Academic Publishing.

Erhueh, A. O. (1989). The dignity of the human person. Theology contemporary Nigerian society. Bulletin of Ecumenical, 2, 2.

Etienne, G. (1960). The breakdown of morals and Christian education.
New York: Danbleday \& Co.

Ezeani, G. B. (1986). The freedom fighters. Ibadan: Juddy Best Publishers.

Ezeanya, S. N. (1976). The dignity of man in the traditional religion of Africa (Unpublished article). University of Nigeria Nsukka.

Ezeanya, S. N. (1979). The contribution of African traditional religion to nation building. In V. C. Chukwulozie (Ed.), Nigerian dialogue. University of Nigeria Nsukka: Nigerian Secretariat for non-Christians.

Flannery, A. (1975). Vatican council II. Dublin: Dominican Publications.

Fulton, S. (1954). Peace of soul. New York: Image Books.

Iheoma, E. O. (1983). Summary of the plenary session dismmision. In O. A. Nduka et al. (Eds.), New Perspectives in moral education. Ibadan: Evans Brother (Nigeria Publishers) Ltd.

Iheoma, E. O. (1995). Moral education. Enugu: Fourth Dimension Publishers.

John, P. J. (1970). Bishop Shanaham of Southern Nigeria. Dublin: Elo Press Ltd.

Mbiti, J. S. (1970). African religion and philosophy. London: Heinemann.

Mbiti, J. S. (1975). An introduction to Africa traditional religion. London: Heinemann.

Mbiti, J. S. (1982). Introduction to African religion. London: Heinemann.

Nwokolo, C. (1984). On the nation's moral decay and economic failure: A challenge to Universities. The Guardian, 18 March.

Ogugua, B. I. (2004). Globalization: Is it enough? Unpublished article.

Okolo, C. B. (1979). Christianity and national-building: A perspective. In Chukwulozie (Ed.), Nigerian dialogue. The Nigerian Secretariat for non-Christians, 3.

Okoye, G. M. P. (1977). The Christian and sense of responsibility. Lenten Pastoral.

Oladipo, O. (1995). Religion and human right: The Nigeria experience. Lagos: Joja Educational.

Omeregbe, J. I. (1993). A philosophical look at religion. Lagos: JOJA Educational research \& publishers Ltd.

Paulo, F. (1973). Pedagogy of the oppressed (Trans myrrh Bergman Ramous). New York: Seabury Press.

Pope VI, F. (1968). Message of his Holiness Pope Paul VI to all the peoples of Africa for the promotion of religious, Civil and social good of their Continent Vatican City.

Porringer, E. C. (1970). Monotheism and Pantheism in Africa. Journal of Religion in Africa, 11, 2.

Sceiermacher, F. D. (1963). The Christian faith. New York: Harper \& Row.

Uche, O. O. C. (2006). The dynamics of religion as a matrix of culture. In N. Ojiakor, \& Iyke (Eds.), Readings in Nigeria peoples and culture. Enugu: NGIB Publishers.

Uche, O. O. C. (2007). Preservation of African cultural values in the 21st Century. In N. Ojiakor (Eds.), Salient issues in Nigerian history, culture and socio political development. Enugu: Emmy Angel Publishers.

Uche, O. O. C. (2009a). Basic belief system in African traditional religion. In F. Aghamelu, \& C. Asomugha (Eds.), Readings in African thought and culture. Enugu: Strong Tower.

Uche, O. O. C. (2009b). The socio-religious significance of taboos in Nigeria. In F. Aghamelu, \& C. Asomugha (Eds.), Readings in African thought and culture. Enugu: Strong Tower.

Uche, O. O. C. (2011). Religion and sustainable development in Nigeria; a functionalist prospective. In A. B. C. Chiegbuka, T. C. Utoh Ezeajuah, \& M. S. Ogene (Eds.), The humanities and sustainable development (pp. 350-359). Nimo: Rex Charles and Patrick.

Von Rad, G. (1965). Genesis: A commentary. Philadelphia: Westminster Press. 